http://dx.doi.org/10.1590/1678-4162-7941

Arq. Bras. Med. Vet. Zootec., v.67, n.6, p.1528-1532, 2015

\title{
Spleen evaluation using contrast enhanced ultrasonography and Doppler in dogs with subclinical ehrlichiosis
}

\author{
[Ultrassonografia por contraste com microbolhas e Doppler na avaliação do \\ baço de cães com erliquiose subclínica] \\ M.C. Maronezi ${ }^{1}$, M.A.R. Feliciano ${ }^{1 *}$, L.Z. Crivellenti ${ }^{1,2}$, S. Borin-Crivellenti ${ }^{1,2}$, P.E.S. Silva ${ }^{1}$, \\ C. Zampolo ${ }^{1}$, L. Pavan ${ }^{1}$, B. Gasser ${ }^{1}$, A.P.R. Simões ${ }^{1}$, G.S. Maciel ${ }^{1}$, \\ J.C. Canola ${ }^{1}$, W.R.R. Vicente ${ }^{1}$ \\ ${ }^{1}$ Faculdade de Ciências Agrárias e Veterinárias, UNESP - Jaboticabal, SP \\ ${ }^{2}$ Pós-graduação - Universidade de Franca (UNIFRAN) - Franca, SP
}

\begin{abstract}
The aim of this study was to evaluate the splenic parenchyma of dogs with subclinical ehrlichiosis using Doppler and contrast-enhanced ultrasonography and provide reference values for this organ in affected animals. Seventeen dogs naturally infected with E. canis were selected for this study. Splenic parenchyma echotexture and echogenicity, size and borders were determined by ultrasound scan. The vascular indices of the splenic artery were determined by Doppler. SonoVue, at $0.1 \mathrm{~mL}$ per animal, was used in microbubble contrast-enhanced ultrasonography to determine wash in, wash out and peak enhancement time in the splenic tissue. B-mode ultrasonography revealed splenomegaly with rounded borders, heterogeneous echotexture and mixed echogenicity. The vascular indices of the splenic artery were: systolic velocity of $22.59 \pm 8.07 \mathrm{~cm} / \mathrm{s}$, diastolic velocity of $5.25 \pm 4.66 \mathrm{~cm} / \mathrm{s}$ and resistance index of $0.71 \pm 0.14$; values not yet reported in Veterinary Medicine. Contrast-enhanced ultrasonography recorded wash in time of $5.31 \pm 0.7 \mathrm{~s}$, peak enhancement time of $18.56 \pm 2.90 \mathrm{~s}$ and wash out time of $94.56 \pm 35.21 \mathrm{~s}$. The combination of conventional ultrasonography of the spleen and hemodynamic evaluation by Doppler and contrast-enhanced ultrasonography is important for the diagnosis of canine ehrlichiosis and could help monitor the clinical evolution of subclinical cases.
\end{abstract}

Keywords: canine, ehrlichiosis, ultrasound

\section{RESUMO}

O objetivo deste estudo foi avaliar o parênquima esplênico de cães com erliquiose na fase subclínica, por meio do Doppler e da ultrassonografia por contraste com microbolhas. Dezessete cães naturalmente infectados por E. canis na fase subclínica foram selecionados para este estudo. Por meio da ultrassonografia, avaliou-se a ecotextura, a ecogenicidade, o tamanho e os bordos do baço e, pelo Doppler, foram determinados os índices vasculares da artéria esplênica dos cães. Para a avaliação por contraste com microbolhas, foi utilizado SonoVue, na dosagem de 0,1mL por animal, e determinou-se o tempo de entrada e saída, bem como o pico de realce no tecido esplênico. Ao exame modo- $B$, foram observadas esplenomegalia com presença de bordas arredondadas, ecotextura heterogênea $e$ ecogenicidade mista do baço. Ao Doppler, foram encontrados valores para os índices vasculares da artéria esplênica: velocidade sistólica: $22,59 \pm 8,07 \mathrm{~cm} / \mathrm{s}$; velocidade diastólica: $5,25 \pm 4,66 \mathrm{~cm} / \mathrm{s}$; e índice de resistência: 0,71 $\pm 0,14$, valores ainda não descritos em veterinária. Pela ultrassonografia com contraste, observaram-se valores para wash-in de 5,31 \pm 0.7 s, pico de realce de $18,56 \pm 2.90$ s e wash-out de 94,56 $\pm 35.21 \mathrm{~s}$. A ultrassonografia convencional do baço de cães com erliquiose, associada com a utilização do método Doppler e a ultrassonografia contrastada, é uma importante ferramenta na triagem diagnóstica e pode auxiliar a monitoração e a evolução de animais na fase subclínica.

Palavras-chave: canino, erliquiose, ultrassom

Recebido em 27 de setembro de 2014

Aceito em 14 de junho de 2015

*Autor para correspondência (corresponding author)

Email: marcusfeliciano@yahoo.com.br 


\section{INTRODUCTION}

Canine ehrlichiosis is caused by gram-negative obligate intracellular bacterium (Davoust et al., 2014; Mylonakis et al., 2014) and although it affects domestic dogs worldwide, it is more prevalent in tropical regions (Trapp et al., 2006). The disease occurs in three phases: acute, subclinical and chronic. The subclinical stage is the most difficult to diagnose, as the dogs are asymptomatic (Davoust et al., 2014).

The spleen is one of the largest reticuloendothelial organs in humans and animals (Morris and Dobson, 2007) and one of the main sites for primary and metastatic tumours and diseases of the hematopoietic system (Morris and Dobson, 2007). The diagnosis of splenic alterations is of paramount importance due to its involvement in lymphatic, immune, circulatory and hematopoietic functions (Fry and McGavin, 2007).

Ultrasonography is a useful imaging method in the evaluation of abnormalities, such as splenomegaly and changes in parenchyma echogenicity and echotexture (Couto, 1992). Thus, ultrasound could be used as an important complementary tool in the diagnosis of canine ehrlichiosis, especially during the subclinical phase.

B-mode, Doppler and contrast-enhanced ultrasonography can also contribute to splenic evaluation. B-mode and Doppler ultrasound provide real time information on the vascular architecture and hemodynamic aspects of the vessels (Carvalho et al., 2008) while microbubble contrast-enhanced ultrasound increases Doppler signal and detects blood flows that are hardly detectable by traditional methods (Nogueira et al., 2002). Most ultrasound contrasting agents are important blood pool agents, making the spleen parenchyma more visible and easier to evaluate, especially during the "vascular phase", (Lim et al., 2004).

Considering the importance of splenic evaluation in animals infected with E. canis, the use of innovative ultrasonographic techniques could provide important information for the diagnosis of subclinical ehrlichiosis. Thus, the aim of this study was to analyse and report, for the first time in Veterinary Medicine, the use of Doppler and microbubble contrast-enhanced ultrasonography in the evaluation of the splenic parenchyma of dogs with subclinical ehrlichiosis.

\section{MATERIAL AND METHODS}

This study was approved by the Ethics Committee in the Use of Animals of the Univ Estadual Paulista- UNESP, Jaboticabal- SP, Brazil (\#11852/14). Seventeen dogs of various breeds, age and weight were selected based on physical examination, clinical history and the absence of clinical signs. Only animals admitted to the Veterinary Hospital for routine check-up or annual vaccine boosters were selected for screening. Complete blood count, biochemical profile, urinalysis and urinary protein:creatinine ratio (UPC) showed minimal alteration. All animals were confirmed positive by PCR and serology.

Ample abdominal trichotomy was performed and gel applied prior to ultrasonography. No sedation was needed.

Ultrasonography was carried out by a single experienced evaluator. B-Mode ultrasonography was performed using an $9.0 \mathrm{MHz}$ linear transducer and ACUSON S2000/SIEMENS ultrasound equipment (Siemens, Munich, Germany). Splenic parenchyma echotexture (homogeneous or heterogeneous) and echogenicity (hypo, hyperechoic or mixed), size (increased, decreased or normal) and borders (rounded or sharp) were recorded.

Pulsed wave Doppler was used to assess the peak systolic velocity (PSV), end-diastolic velocity (EDV) and resistance index (RI = [PSV - EDV] / PSV) of the splenic artery through the use of electronic callipers (Feliciano et al. 2013).

Doppler ultrasonography was performed to determine vessel volume using the uniform insonation method described by Feliciano et al. (2013). A gate of 2 to 3 millimeters (equivalent to $2 / 3$ of vessel diameter) was positioned in the central area of the vessel to measure the spectral flow, curve and vascular index; which were obtained automatically by software identification of the ultrasonic scanner for each waveform. A minimum of three subsequent waves was obtained. There were no artefacts on the tracing and the angle of insonation was adjusted to $<60^{\circ}$. 
Microbubble contrast-enhanced ultrasonography used SonoVue (sulphur hexafluoride) (Bracco Suisse SA, Plan-les-Ouates, Suisse) at $0.1 \mathrm{~mL}$ per animal, which was given through a catheter in the cephalic vein followed by $5 \mathrm{~mL}$ of saline solution (Saline solution 0.9\%). In conjunction with contrast-enhanced ultrasonography, B-mode and Doppler were used to determine wash in, wash out and peak enhancement time of the contrast in the splenic tissue (Takeda et al., 2012).

Vascular indices, wash in, peak enhancement and wash out times were expressed as means and standard deviations. The nonparametric data (echotexture, echogenicity, size and margins) were evaluated using descriptive analysis.

\section{RESULTS AND DISCUSSION}

B-mode ultrasound examination detected splenomegaly with rounded borders, heterogeneous echotexture and mixed echogenicity (hyperechoic and hypoechoic areas) in all animals with ehrlichiosis. Multi-organ dysfunction with liver and spleen involvement are common in clinical cases of canine ehrlichiosis (Ganguly and Mukhopadhayay, 2008). Similarly to the present study, Sarma et al. (2014) observed splenomegaly and mixed echogenicity in animals positive for tick disease. These alterations may result from reactive lymphoid hyperplasia and concurrent extramedullary hematopoiesis (Egenvall et al., 2000) due to the multiplication of the organism within circulating mononuclear cells and/or splenic mononuclear phagocytic tissues (Hildebrandt et al., 1963), even during the subclinical phase.

The B-mode and contrast-enhanced ultrasonography of the spleen were easily performed; however, Doppler scanning of the splenic artery was met with some difficulty due to the respiratory movements of the patients, which hindered the determination of the tracings and prolonged the examination time.
Information on the Doppler technique is limited to characterization of the splenic vascularization using pulsed Doppler tracing (Albernaz et al., 2007; Santarém et al., 2008). The vascular indices of the splenic artery obtained by Doppler were: PSV of $22.59 \pm 8.07 \mathrm{~cm} / \mathrm{s}$, EDV of $5.25 \pm 4.66 \mathrm{~cm} / \mathrm{s}$ and RI of $0.71 \pm 0.14$. These vascular indices are important in animals infected with haemoparasites and could be useful in the therapeutic monitoring of patients that lack clinical signs.

Contrast-enhanced ultrasonography revealed wash-in time of $5.31 \pm 0.7 \mathrm{~s}$, peak enhancement time of $18.56 \pm 2.90 \mathrm{~s}$ and wash out time of $94.56 \pm 35.21 \mathrm{~s}$ (Figure 1), which were lower than those reported in the literature. The mean splenic wash in time in healthy dogs is 13.2 seconds (Ohlerth et al., 2007) and 12.0 seconds in humans (Catalano et al. 2004). Approximately 50 seconds after the injection of SonoVue, the splenic parenchyma becomes homogeneous (peak enhancement) and a dense enhancement persists for up to 5 to 7 minutes (wash out) (Catalano et al. 2004). The peak enhancement time in healthy dogs is $29.8 \pm 11.6$ seconds (Ohlerth et al. 2007).

The splenic alterations detected by conventional ultrasonography, Doppler and contrast-enhanced ultrasonography in this study are due to vasculitis and splenitis, as described in patients with ehrlichiosis (Albernaz et al., 2007; Santarém et al., 2008). Splenitis occurs due to increased splenic activity as a result of parenchyma inflammation and vasculitis, which alter splenic tissue characteristics and vascularization. These changes are reflected in the echotexture and echogenicity of the parenchyma and in the increased blood flow; highlighting that the combination of B-mode, Doppler and contrast-enhanced ultrasonography could be useful in the diagnosis and in therapeutic monitoring of dogs with subclinical ehrlichiosis. 

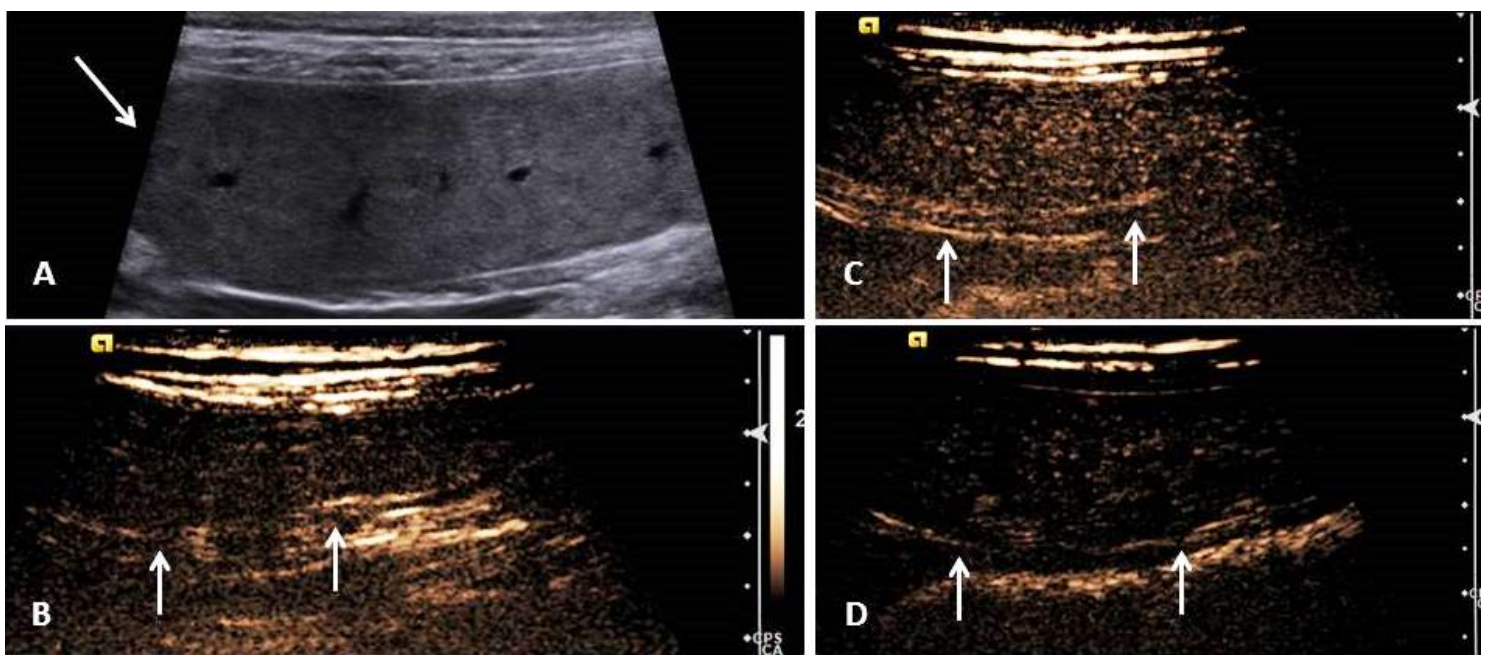

Figure 1. Ultrasound image of the spleen of a dog with subclinical ehrlichiosis: (A) B-mode image of the splenic parenchyma (arrows) with mixed echogenicity and heterogeneous echotexture; image of contrastenhanced ultrasonography of wash in (B), peak enhancement $(C)$ and wash out (D) phases of the splenic parenchyma contrast (arrows).

\section{CONCLUSION}

Conventional ultrasonography of the spleen of dogs with ehrlichiosis and hemodynamic evaluation by Doppler and contrast-enhanced ultrasonography are important diagnostic tools and could aid in the monitoring of the clinical evolution of patients during the subclinical phase.

\section{ACKNOWLEDGEMENTS}

The authors would like to thank FAPESP for the research grant and the Young Researcher scholarship awarded (\# 2012/16635-2, 2013/06443-1 and 2014/21506-2).

\section{REFERENCES}

ALBERNAZ, A.P.; MIRANDA, F.J.B.; MELO JR., O.A. et al. Canine ehrlichiosis in Campos dos Goytacazes, Rio de Janeiro, Brazil. Ciência Animal Brasileira, v.8, n.4, p.799-806, 2007.

CARVALHO, C.F.; CHAMMAS, M.C.; COGLIATI, B. et al. Elastography and contrast-enhanced ultrasonography improves early detection of hepatocellular carcinoma in experimental model of NASH. J. Clin. Exp. Hepatol., v.3, p.96-101, 2013.

CATALANO, O.; CUSATI, B.; NUNZIATA, A.; SIANI, A. Real time, contrast specific sonography imaging of acute splenic disorders: a pictorial review. Emergency Radiol., v.11, p.15-21, 2004.
COUTO C.G. Moléstias dos linfonodos e baço. In: ETTINGER S.F.; FELDMAN E.C. (Eds). Tratado de medicina interna veterinária: moléstias do cão e do gato. 2.ed. São Paulo: Manole, 1992. p.2328-2348.

DAVOUST, B.; PARZY, D.; JEAN-PAUL, D. et al. Usefulness of a rapid immuno-migration test for thedetection of canine monocytic ehrlichiosis in Africa. Comp. Immunol., Microbiol. Infect. Dis., v.37, p.31-37, 2014

EGENVALL, A.; LILLIEHOOK, I.; BJOERSDORFF, A. et al. Detection of granulocytic Ehrlichia species DNA by PCR in persistently infected dogs. Vet. Rec., v.146, p.186-190, 2000.

FELICIANO, M.A.R.; NEPOMUCENO, A.C.; CRIVELARO, R.M. et al. Foetal echoencephalography and Doppler ultrasonography of the middle cerebral artery in canine foetuses. J. Small Anim. Pract., v.54, p.149-152, 2013.

FRY, M.M.; McGAVIN, M.D. Bone marrow, blood cells and lymphatic system. In: MCGAVIN, M.D. (Ed.). Pathologic basis of veterinary disease. 4.ed. St. Louis: Mosby, 2007. 801p.

GANGULY, S.; MUKHOPADHAYAY, S.K. Tickborne ehrlichiosis infection in human beings. J. Vec. Borne Dis., v.45, p.273-280, 2008.

HILDEBRANDT, A.C.; WILMAR, J.C.; JOHN, H.; RIKER, A.J. Growth of edible chlorophyllous plant tissues in vitro. Am. J. Bot., v.50, p.248-254, 1963.

LIM, A.; PATEL, N.; ECKERSLEY, R. et al. Evidence for spleen-specific uptake of a microbubble contrast agent: a quantitative study in healthy volunteers. Radiology, v.231, p. 785-788, 2004. 
MORRIS, J.; DOBSON, J. Tumores variados. In: . Oncologia em pequenos animais. São Paulo Roca, 2007. p.272-278.

MYLONAKIS, M.E.; XENOULIS, P.G.; THEODOROU, K. et al. Serum canine pancreatic lipase immunoreactivity in experimentally induced and naturally occurring canine monocytic ehrlichiosis (Ehrlichia canis). Vet. Microbiol., v.169, p.198-202, 2014.

NOGUEIRA, A.C.; MORCERF, F.; MORAES, A.V. et al. Ultra-sonografia com agentes de contrastes por microbolhas na avaliação da perfusão renal em indivíduos normais. Rev. Bras. Ecocardiogr., v.1, p.74-78, 2002.

OHLERTH, S.; EVA, R.U.E.; VALERIE, P. et al. Contrast harmonic imaging of the normal canine spleen. Vet. Radiol. Ultrasoun., v.48, p.451-456, 2007.
SANTARÉM, V.A.; JOSÉ, M.D.; LAPOSY, C.B. Alterações bioquímicas em cães citopênicos e não citopênicos com ehrlichiose. Semina: Cienc. Agri., v.29, p.845-852, 2008.

SARMA, K.; MONDAL, D.B.; SARAVANAN, M. Ultrasonographic changes in dogs naturally infected with tick borne intracellular diseases. J Parasit Dis, v.june, p.1-4, 2014.

TAKEDA, C.S.I.; CARVALHO, C.F.; CHAMMAS, M.C. Ultrassonografia contrastada na medicina veterinária - revisão. Clín. Vet., v.17, p.108-114, 2012.

TRAPP, S.M.; DAGNONE, A.S.; VIDOTTO, O. et al. Seroepidemiology of canine babesiosis and ehrlichiosis in a hospital population. Vet. Parasitol., v.140, p.223-230, 2006. 